\title{
Natural ocean acidification at Papagayo upwelling system (north Pacific Costa Rica): implications for reef development
}

\author{
Celeste Sánchez-Noguera ${ }^{1,2}$, Ines Stuhldreier ${ }^{1,3}$, Jorge Cortés ${ }^{2}$, Carlos Jiménez ${ }^{4,5}$, Álvaro Morales ${ }^{2,6}$, Christian Wild ${ }^{3}$, \\ and Tim Rixen ${ }^{1,7}$ \\ ${ }^{1}$ Leibniz Centre for Tropical Marine Research (ZMT), Bremen, Germany \\ ${ }^{2}$ Centro de Investigación en Ciencias del Mar y Limnología (CIMAR), Universidad de Costa Rica, San José, Costa Rica \\ ${ }^{3}$ Faculty of Biology and Chemistry (FB2), University of Bremen, Bremen, Germany \\ ${ }^{4}$ Energy, Environment and Water Research Center (EEWRC) of the Cyprus Institute (CyI), Nicosia, Cyprus \\ ${ }^{5}$ Enalia Physis Environmental Research Centre (ENALIA), Aglanjia, Nicosia, Cyprus \\ ${ }^{6}$ Escuela de Biología, University of Costa Rica, San José, Costa Rica \\ ${ }^{7}$ Institute of Geology, University Hamburg, Hamburg, Germany
}

Correspondence: Celeste Sánchez-Noguera (celeste08@gmail.com)

Received: 28 October 2017 - Discussion started: 13 November 2017

Revised: 15 March 2018 - Accepted: 23 March 2018 - Published: 19 April 2018

\begin{abstract}
Numerous experiments have shown that ocean acidification impedes coral calcification, but knowledge about in situ reef ecosystem response to ocean acidification is still scarce. Bahía Culebra, situated at the northern Pacific coast of Costa Rica, is a location naturally exposed to acidic conditions due to the Papagayo seasonal upwelling. We measured $\mathrm{pH}$ and $p \mathrm{CO}_{2}$ in situ during two non-upwelling seasons (June 2012, May-June 2013), with a high temporal resolution of every 15 and $30 \mathrm{~min}$, respectively, using two Submersible Autonomous Moored Instruments (SAMI-pH, SAMI-CO2). These results were compared with published data from the 2009 upwelling season. Findings revealed that the carbonate system in Bahía Culebra shows a high temporal variability. Incoming offshore waters drive intra- and interseasonal changes. Lowest $\mathrm{pH}$ (7.8) and highest $p \mathrm{CO}_{2}$ (658.3 $\mu \mathrm{atm})$ values measured during a cold-water intrusion event in the non-upwelling season were similar to those minimum values reported from upwelling season $(\mathrm{pH}=7.8$, $\left.p \mathrm{CO}_{2}=643.5 \mu \mathrm{atm}\right)$, unveiling that natural acidification also occurs sporadically in the non-upwelling season. This affects the interaction of photosynthesis, respiration, calcification and carbonate dissolution and the resulting diel cycle of $\mathrm{pH}$ and $p \mathrm{CO}_{2}$ in the reefs of Bahía Culebra. During the non-upwelling season, the aragonite saturation state $\left(\Omega_{\mathrm{a}}\right)$ rises to values of $>3.3$ and during the upwelling season falls below 2.5. The $\Omega_{\mathrm{a}}$ threshold values for coral growth were
\end{abstract}

derived from the correlation between measured $\Omega_{\mathrm{a}}$ and coral linear extension rates which were obtained from the literature and suggest that future ocean acidification will threaten the continued growth of reefs in Bahía Culebra. These data contribute to building a better understanding of the carbonate system dynamics and coral reefs' key response (e.g., coral growth) to natural low-pH conditions, in upwelling areas in the eastern tropical Pacific and beyond.

\section{Introduction}

Ocean acidification (OA) caused by human-induced increase of atmospheric $\mathrm{CO}_{2}$ (Sabine et al., 2004; Feely et al., 2009) is considered one of the major threats to marine calcifying organisms and ecosystems (Fabry et al., 2008; Hofmannn et al., 2010; Doney et al., 2012; Gattuso et al., 2015). Among all marine habitats, tropical coral reefs are recognized as the most endangered (Hoegh-Guldberg et al., 2007; Kleypas and Yates, 2009; Pörtner et al., 2014), since in addition to reduced calcification (Langdon et al., 2000; Marubini et al., 2008; Doney et al., 2009; Gattuso et al., 2014), a lower pH also weakens the reef framework by favoring bioerosion and enabling carbonate dissolution (Gattuso et al., 2014; Manzello et al., 2014; Barkley et al., 2015). According to the IPCC business-as-usual scenario, about $90 \%$ of the ocean's sur- 
face waters will become undersaturated with respect to aragonite in the next decades (Gattuso et al., 2015), emphasizing the need to study the response of natural ecosystems to OA. Nowadays, aragonite undersaturated surface waters occur naturally in some parts of the ocean, as a consequence of underwater volcanic seeps (Hall-Spencer et al., 2008; Fabricius et al., 2011, 2015; Enochs et al., 2015) or upwelling that drags corrosive deep water into the surface mixed layer (Feely et al., 2008; Hauri et al., 2009; Fassbender et al., 2011; Harris et al., 2013).

Aside from some studies at volcanic seeps (Fabricius et al., 2011, 2015; Kroeker et al., 2011; Enochs et al., 2015) or at reefs in the eastern tropical Pacific (ETP) (Manzello, 2008, 2010a, b; Manzello et al., 2008, 2014), our understanding of OA impacts on corals derives mainly from laboratory and seawater enclosure experiments (Pörtner et al., 2014; Hall-Spencer et al., 2015). These results are used to predict ecosystem responses to future OA (Kleypas et al., 2006; Kleypas and Langdon, 2006), but their reliability is challenged by the artificial conditions under which the experiments are conducted. For example, the duration of studies is often too short to allow a full adaptation or acclimatization of the organisms/systems to the changing environmental conditions, and the missing connectivity between ecosystems in seawater enclosures restricts natural interactions between organisms (Kleypas et al., 2006; Kleypas and Langdon, 2006; Hofmann et al., 2010). In situ studies in natural low-pH conditions are able to overcome some of these problems and the ETP is well known for its $\mathrm{CO}_{2}$-enriched and acidic subsurface waters (Takahashi et al., 2014). Upwelling events decrease the carbonate saturation state $(\Omega)$ along the Central American coast (Manzello et al., 2008; Manzello, 2010b; Rixen et al., 2012) and have the potential to produce poorly cemented coral reefs with low accretion rates that are subject to rapid bioerosion (Manzello et al., 2008; Alvarado et al., 2012).

Corals in the northern part of the Costa Rican Pacific coast are developing under the influence of the seasonal Papagayo upwelling (Jiménez et al., 2010; Rixen et al., 2012; Stuhldreier et al., 2015a, b). To contribute to the general understanding of OA impacts on coral reefs, we investigated the variability of the carbonate system in the upwellinginfluenced Bahía Culebra, Costa Rica. The main objectives of this study were (1) to describe the behavior of the carbonate system on diurnal and seasonal timescales, (2) to characterize the controlling processes and (3) to determine ecological impacts of changing carbonate systems. Furthermore, our results will allow us to draw some conclusions concerning future thresholds of coral reef development within this bay.

\section{Methods}

\subsection{Study site}

Bahía Culebra, located in the Gulf of Papagayo, North Pacific coast of Costa Rica (Fig. 1), is strongly influenced by the north easterly Papagayo winds. The strongest wind jets develop during the boreal winter (Amador et al., 2016) and are driven by large-scale variations of the trade winds (Chelton et al., 2000; Alfaro and Cortés, 2012). When Papagayo winds blow through the mountain gap between southern Nicaragua and northern Costa Rica, the resulting strong offshore winds on the Pacific side can lead to upwelling of cold and nutrient-enriched subsurface waters between December and April (McCreary et al., 1989; Brenes et al., 1990; Ballestero and Coen, 2004; Kessler, 2006). These cyclonic eddies also influence the magnitude and location of the Costa Rica Dome (CRD), which is located approx. $300 \mathrm{~km}$ off the Gulf of Papagayo (Fiedler, 2002). However, the CRD changes its distance to the Costa Rican coast throughout the year, as a result of differences in wind forcing (Wyrtki, 1964; Fiedler, 2002). During the dry season, particularly between February and April, offshore moving water masses strengthen upwelling at the coast and shoal the thermocline in the Gulf of Papagayo (Wyrtki, 1965, 1966; Fiedler, 2002). In May-June, during the onset of the rainy season, the CRD moves offshore (Fiedler, 2002; Fiedler and Talley, 2006) and the North Equatorial Countercurrent (NECC) can carry tropical water masses into Bahía Culebra until December, when upwelling sets in again (Wyrtki, 1965, 1966).

\subsection{Measurements}

We measured in situ $\mathrm{pH}, p \mathrm{CO}_{2}$ and seawater temperature (SWT) during two non-upwelling periods (15 days in June 2012 and 7 days in May-June 2013; Fig. 2). Measurements were undertaken with two Submersible Autonomous Moored Instruments (SAMI-pH and SAMI-CO ${ }_{2}$ ) (www.sunburstsensors.com, last access: 10 April 2017), in sampling intervals of 15 (June 2012) and $30 \mathrm{~min}$ (MayJune 2013). SAMI sensors were deployed at the pier of Marina Papagayo $\left(85^{\circ} 39^{\prime} 21.41^{\prime \prime} \mathrm{W}, 10^{\circ} 32^{\prime} 32.89^{\prime \prime} \mathrm{N}\right)$, on top of a carbonate sandy bottom in the inner part of Bahía Culebra (Fig. 1). The water depth varied approximately between 5 and $8 \mathrm{~m}$ depending on the tide, but sensors, hooked to the pier, moved up and down with the tide and were always at the same depth, $1.5 \mathrm{~m}$ below the surface. SAMI instruments measured $\mathrm{pH}$ (total hydrogen ion scale) and $\mathrm{CCO}_{2}$ spectrophotometrically by using a colorimetry reagent method (DeGrandpre et al., 1995, 1999; Seidel et al., 2008). Salinity from discrete samples was measured with a WTW probe (Cond3310) and was used for correction of $\mathrm{pH}$ values. Calculation of aragonite saturation state $\left(\Omega_{\mathrm{a}}\right)$ from parameters measured in situ with SAMI sensors is accurate (Cullison Gray et al., 2011; Gray et al., 2012), but discrete water sam- 


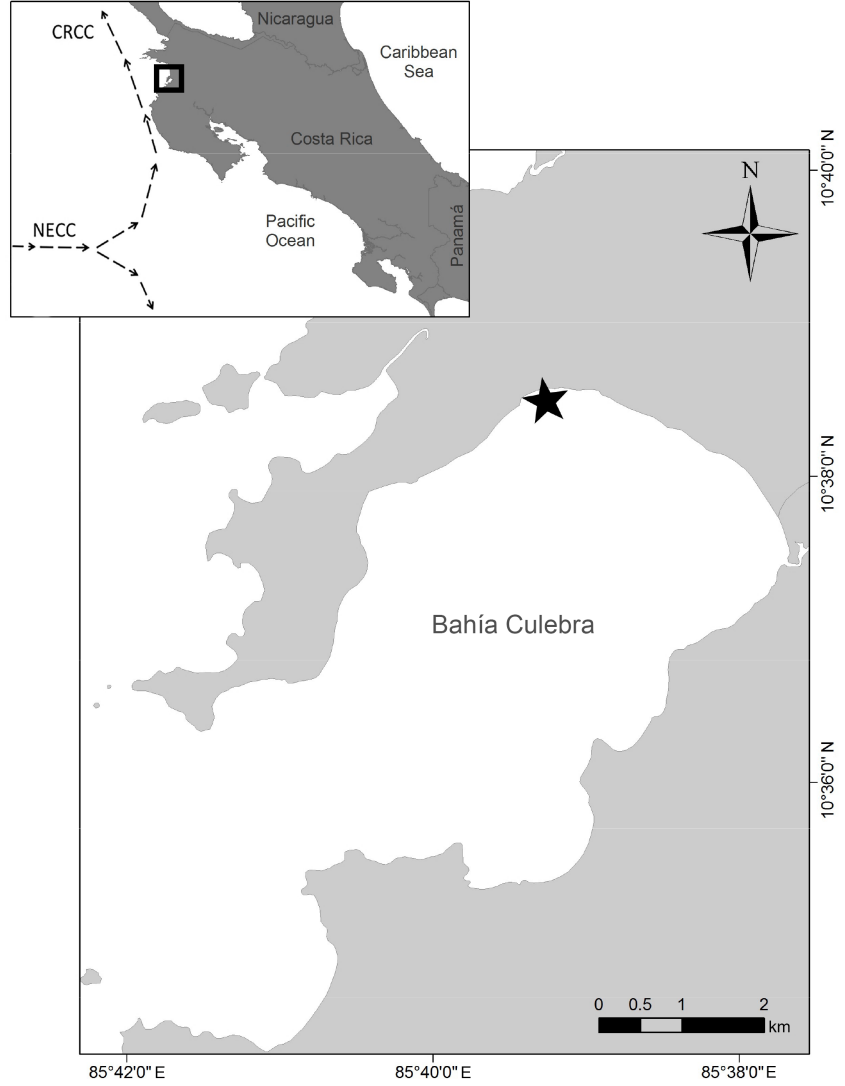

Figure 1. Location of Bahía Culebra (square) in the Gulf of Papagayo, North Pacific coast of Costa Rica (insert). Measurements were made at Marina Papagayo (star). Main ocean currents influencing the Gulf of Papagayo (dashed arrows): NECC indicates the North Equatorial Countercurrent; CRCC indicates the Costa Rica Coastal Current.

ples were collected as often as possible to validate the instruments (Fig. 3). The $250 \mathrm{~mL}$ borosilicate bottles were filled with seawater at $30 \mathrm{~cm}$ below the surface and preserved with $200 \mu \mathrm{L}$ of $50 \%$ saturated $\mathrm{HgCl}_{2}$ solution to inhibit biological activity (Dickson et al., 2007). Samples were stored at $3-4{ }^{\circ} \mathrm{C}$ until analysis. Total alkalinity (TA) and dissolved inorganic carbon (DIC) were measured using a VINDTA 3C (Versatile INstrument for the Determination of Total inorganic carbon and titration Alkalinity; Marianda, Kiel, Germany) coupled with a UIC $\mathrm{CO}_{2}$ coulometer detector (UIC Inc., Joliet, USA). Both instruments were calibrated with Dickson Certified Reference Material (Batch 127) (Dickson et al., 2003). DIC concentrations as well as TA and $\Omega_{\mathrm{a}}$ were calculated with the $\mathrm{CO} 2 \mathrm{SYS}$ program as a function of measured $\mathrm{pH}$ and $p \mathrm{CO}_{2}$, with dissociation constants of Mehrbach et al. (1973) for carbonic acid as refit by Dickson and Millero (1987) and Dickson (1990) for boric acid.

Wind speeds were obtained from a station of the Instituto Metereológico Nacional (National Meteorological Institute of Costa Rica), located at the nearby Liberia airport. The (a)

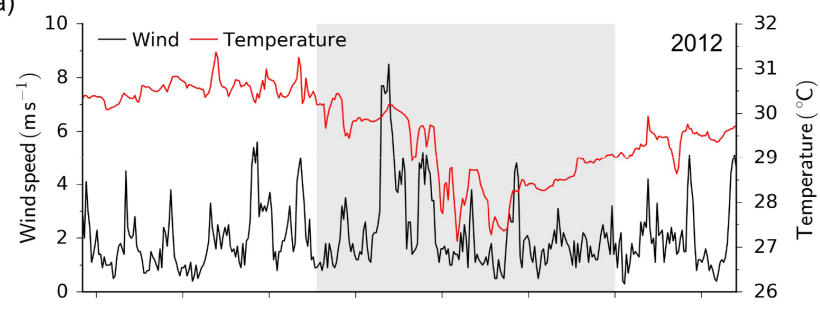

(b)

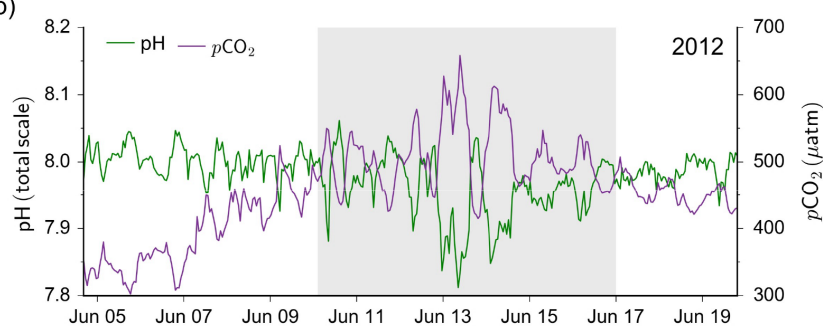

(c)

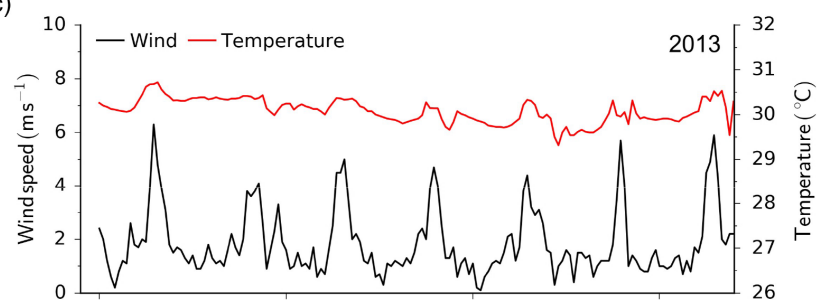

(d)

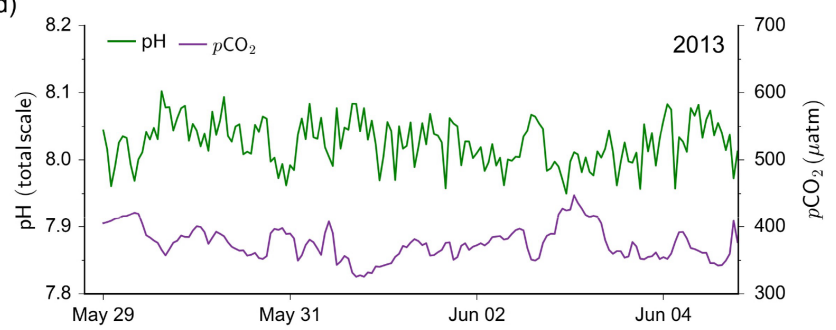

Figure 2. Measured parameters (wind speed, SWT, $\mathrm{pH}$ and $p \mathrm{CO}_{2}$ ) during the non-upwelling seasons of June 2012 (a, b) and MayJune 2013 (c, d) at Bahía Culebra. Shaded area in panels (a, b) indicates the 2012 upwelling-like event.

Módulo de Información Oceanográfica of the University of Costa Rica (www.miocimar.ucr.ac.cr, last access: 27 September 2016) supplied the tidal data. All coral growth values were taken from the literature; linear extension rates from Bahía Culebra were measured by Jiménez and Cortés (2003), whilst coral growth in Panama and Galápagos was measured by Manzello (2010a). For the correlation between coral growth and $\Omega_{\mathrm{a}}$, we used the mean $\Omega_{\mathrm{a}}$ values from Panama and Galápagos previously reported by Manzello (2010b).

\subsection{Data analysis}

We compared our data with values measured during the upwelling season in 2009 (Rixen et al., 2012). In 2009, $x \mathrm{CO}_{2}$ was measured by an underway $p \mathrm{CO}_{2}$ system (SUNDANS) equipped with an infrared gas analyzer (LI-7000), 

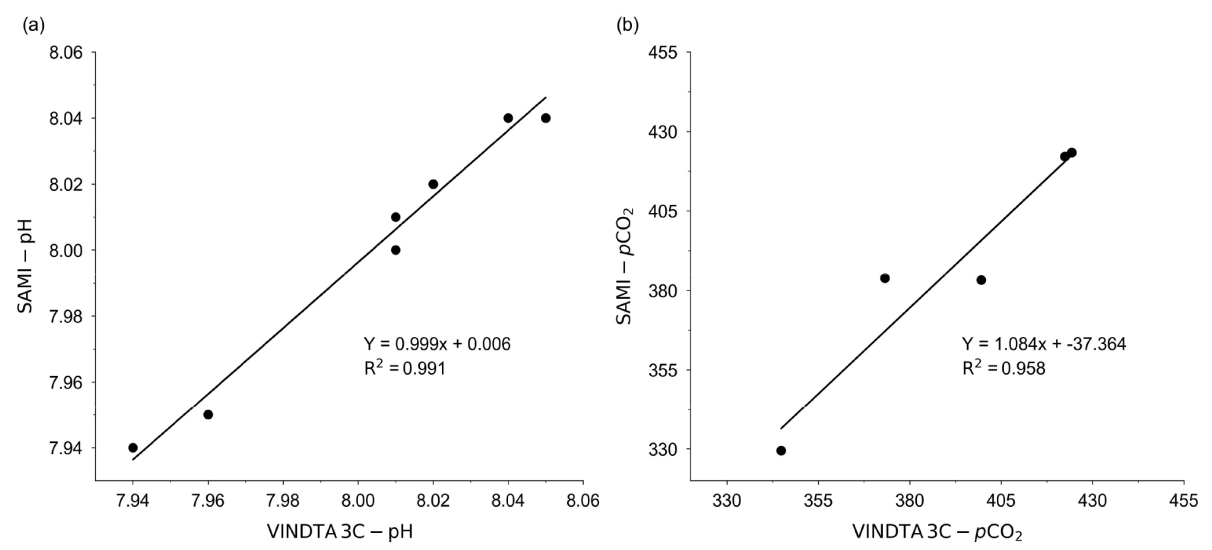

Figure 3. Validation of in situ measurements of $\mathrm{pH}(\mathbf{a})$ and $p \mathrm{CO}_{2}$ (b) using discrete water samples. SAMI sensors measured $\mathrm{pH}$ and $p \mathrm{CO}_{2}$ directly in the water column. The $\mathrm{pH}$ and $\mathrm{pCO}_{2}$ values used for validation were calculated with the CO2SYS program as a function of measured TA and DIC; discrete samples were measured with a VINDTA 3C system.

and $\mathrm{pH}$ was measured using an Orion ROSS electrode (an Orion $\mathrm{Star}^{\mathrm{TM}}$ ). Correlations between tidal cycles and physicochemical parameters $\left(\mathrm{pH}, p \mathrm{CO}_{2}, T\right.$, wind) during nonupwelling periods were tested via Pearson correlation in Python. Differences in parameters (temperature, $\mathrm{pH}, p \mathrm{CO}_{2}$, TA, DIC and $\Omega_{\mathrm{a}}$ ) between all periods $(2009,2012,2013)$ were tested with a general linear model (GLM) in the statistical package R. The GLM was evaluated using graphical methods to identify violations of assumptions of homogeneity of variance and normality of residuals. All GLM assumptions were met. Additionally, we developed a simple model to improve our understanding of processes controlling the observed diel trends, as seen in the time series data of $\mathrm{pH}$ and $\mathrm{pCO}_{2}$ (Figs. 2, 4). The model simulates combined effects of metabolic processes (photosynthesis, respiration, calcification and dissolution) on the carbonate chemistry. Input parameters for starting the model were the calculated DIC (in 2012: $2037 \mu \mathrm{mol} \mathrm{kg}-1$ at 07:00 UTC -6 and $2019 \mu \mathrm{mol} \mathrm{kg}^{-1}$ at 15:00; in 2013: $1883 \mu \mathrm{mol} \mathrm{kg}{ }^{-1}$ at 05:00 and $1805 \mu \mathrm{mol} \mathrm{kg}^{-1}$ at 15:00) and TA (in 2012: $2284 \mu \mathrm{mol} \mathrm{kg}^{-1}$ at 07:00; in 2013: $2193 \mu \mathrm{mol} \mathrm{kg}-1$ at 05:00) values, corresponding to the highest and lowest measured $p \mathrm{CO}_{2}$ during the day. Calculation of TA and DIC from the pair $\mathrm{pH}$ and $p \mathrm{CO}_{2}$ is prone to errors (Millero, 2007; Cullison Gray et al., 2011); however, the values used as input parameters in the model are in range with those reported from other studies in tropical areas (Manzello, 2010b; Cyronak et al., 2013b). The difference between the two DIC concentrations $(\triangle D I C)$ was assumed to be caused by photosynthesis and respiration and the resulting formation and decomposition of particulate organic carbon (POC), as well as calcification and dissolution and the precipitation and dissolution of particulate inorganic carbon (PIC, Eq. 1). $R_{\mathrm{OI}}$ describes the ratio between the production of organic carbon (POC) and precipitation of calcium carbonate carbon (PIC) and was used to link $\Delta$ POC to $\Delta$ PIC $\left(R_{\mathrm{OI}}=\right.$ POC $/$ PIC) (Eq. 2,3$)$. The
$R_{\mathrm{OI}}$ was further constrained by the determined change of TA $(\triangle \mathrm{TA})$. Therefore, it was considered that photosynthesis and respiration of one mole of carbon increases and reduces TA by 0.15 units, respectively (Broecker and Peng, 1982). Calcification and dissolution of one mole of carbon decreases and increases TA by two units (Eq. 4). To verify the results from the model, we used the output $\triangle \mathrm{DIC}$ and $\Delta \mathrm{TA}$ to calculate new $p \mathrm{CO}_{2}$ and $\mathrm{pH}$ values, which were further compared to the measured ones (Fig. 5). The best fit between modeled and measured values was achieved with a respective $R_{\mathrm{OI}}$ of -2.6 for 2012 and 1.0 for 2013, whereas the assumption of calcium carbonate dissolution caused the negative sign.

$$
\begin{aligned}
& \Delta \mathrm{DIC}=\Delta \mathrm{POC}+\Delta \mathrm{PIC} \\
& \Delta \mathrm{PIC}=\left(\frac{\Delta \mathrm{POC}}{R_{\mathrm{OI}}}\right) \\
& \Delta \mathrm{POC}=\Delta \mathrm{DIC} /\left(1+\left(\frac{1}{R_{\mathrm{OI}}}\right)\right) \\
& \Delta \mathrm{TA}=(\Delta \mathrm{POC} \cdot 0.15)-\left(\left(\frac{\Delta \mathrm{POC}}{R_{\mathrm{OI}}}\right) \cdot 2\right)
\end{aligned}
$$

This was calculated on hourly time steps, separately for 2012 and 2013, using the mean SWT $\left(2012=29.61 \pm 0.93^{\circ} \mathrm{C}\right.$, $\left.2013=30.08 \pm 0.27^{\circ} \mathrm{C}\right) \quad$ and salinity $\quad(2012=32.5$, $2013=32.5)$.

\section{Results}

\subsection{Carbonate chemistry during the non-upwelling season}

In June 2012, average SWT was $29.61 \pm 0.93$ (average \pm standard deviation) ${ }^{\circ} \mathrm{C}$ and ranged from 27.13 to $31.37^{\circ} \mathrm{C}$. In May-June 2013 , SWT ranged from 29.3 to $30.7^{\circ} \mathrm{C}$ (average $30.08 \pm 0.27^{\circ} \mathrm{C}$ ). During both periods, the salinity was $32.5 \pm 0.8$. During the study periods, the 
Table 1. Measured and calculated $\left(^{*}\right)$ parameters, during upwelling (2009) and non-upwelling seasons (2012, 2013) at Bahía Culebra, Costa Rica.

\begin{tabular}{|c|c|c|c|c|c|c|c|}
\hline & $\begin{array}{c}\mathrm{pH} \\
\text { (total scale) }\end{array}$ & $\begin{array}{l}p \mathrm{CO}_{2} \\
(\mu \mathrm{atm})\end{array}$ & $\begin{array}{c}\mathrm{CO}_{2} \\
\left(\mu \mathrm{mol} \mathrm{kg}{ }^{-1}\right)\end{array}$ & $\begin{array}{c}T \\
\left({ }^{\circ} \mathrm{C}\right)\end{array}$ & $\begin{array}{c}\mathrm{DIC}^{*} \\
\left(\mu \mathrm{mol} \mathrm{kg}{ }^{-1}\right)\end{array}$ & $\begin{array}{c}\mathrm{TA}^{*} \\
\left(\mu \mathrm{mol} \mathrm{kg}{ }^{-1}\right)\end{array}$ & $\Omega^{*}$ \\
\hline \multicolumn{8}{|l|}{2009} \\
\hline $\begin{array}{l}\text { Mean } \pm S D \\
2012\end{array}$ & $7.91 \pm 0.32$ & $578.49 \pm 42.82$ & $16.44 \pm 1.35$ & $25.09 \pm 0.57$ & $2098.71 \pm 103.81$ & $2328.42 \pm 118.45$ & $2.71 \pm 0.29$ \\
\hline $\begin{array}{l}\text { Mean } \pm \text { SD } \\
2013\end{array}$ & $7.98 \pm 0.04$ & $456.38 \pm 69.68$ & $11.77 \pm 1.99$ & $29.61 \pm 0.93$ & $1924.65 \pm 195.07$ & $2204.54 \pm 212.18$ & $3.32 \pm 0.46$ \\
\hline Mean \pm SD & $8.02 \pm 0.03$ & $375.67 \pm 24.25$ & $9.56 \pm 0.64$ & $30.08 \pm 0.27$ & $1800.92 \pm 142.78$ & $2102.66 \pm 174.79$ & $3.50 \pm 0.49$ \\
\hline
\end{tabular}
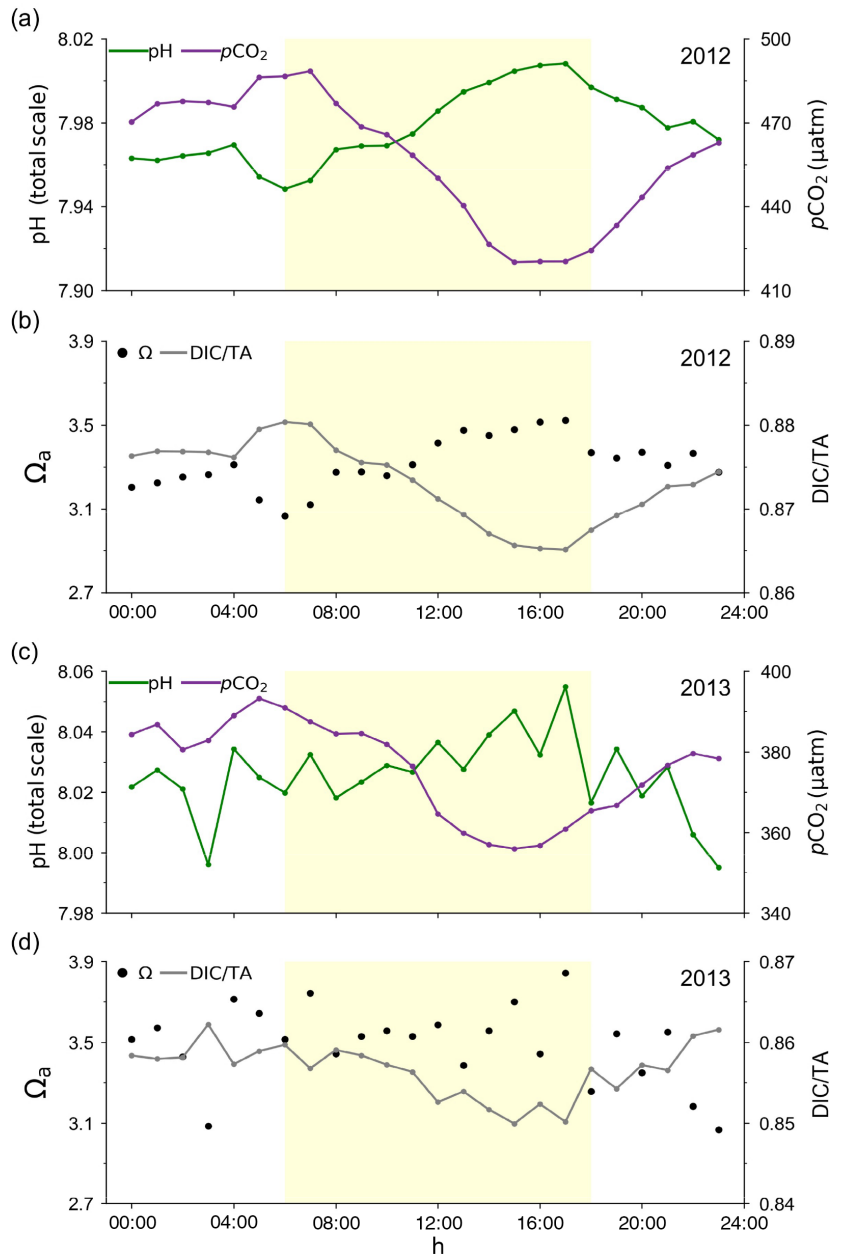

Figure 4. Diel pattern of parameters measured in Bahía Culebra. Data points are hourly averages of 15 and 7 consecutive days in 2012 (a, b) and 2013 (c, d), respectively. The shaded area represents daylight hours.

wind intensified during the afternoons, reaching speeds of up to 8.5 and $6.0 \mathrm{~m} \mathrm{~s}^{-1}$ in 2012 and 2013 , respectively (Fig. 2). Average $\mathrm{pH}$ and $p \mathrm{CO}_{2}$ in June 2012 were $7.98 \pm 0.04$ and $456.38 \pm 69.68 \mu \mathrm{atm}$, respectively; the corresponding averages for May-June 2013 were $8.02 \pm 0.03$ and $375.67 \pm 24.25 \mu \mathrm{atm}$. Since the tidal cycle was not significantly correlated with the variability of $\mathrm{pH}, p \mathrm{CO}_{2}, T$ or wind $(p>0.05)$ during the periods of observations (Table 2), it was excluded from further discussions. Mean $\Omega_{\mathrm{a}}$ values were $3.32 \pm 0.46$ in June 2012 and $3.50 \pm 0.49$ in May-June 2013 (Table 1).

\subsection{Seasonal variation of the carbonate system}

Measured parameters showed significant differences between study periods $(p<0.05)$. The SWT range differed among years (Table 1); 2013 was the warmest study period, followed by 2012 and 2009. Lowest measured $\mathrm{pH}$ was 7.81 in June 2012, 7.84 in April 2009 and 7.95 in MayJune 2013. We also compared DIC and TA, in order to estimate to which extent the observed variations of $p \mathrm{CO}_{2}$ were caused by changes in temperature and/or DIC concentrations. Mean DIC values were $2098.71 \pm 103.81 \mu \mathrm{mol} \mathrm{kg}{ }^{-1}$ in April 2009, $1924.65 \pm 195.07 \mu \mathrm{mol} \mathrm{kg}^{-1}$ in June 2012 and $1800.92 \pm 142.78 \mu \mathrm{mol} \mathrm{kg}^{-1}$ in May-June 2013. Similarly, mean TA values were $2328.42 \pm 118.45 \mu \mathrm{mol} \mathrm{kg}{ }^{-1}$ in April 2009, 2204.54 $\pm 212.18 \mu \mathrm{mol} \mathrm{kg}^{-1}$ in June 2012 and $2102.66 \pm 174.79 \mu \mathrm{mol} \mathrm{kg}{ }^{-1}$ in May-June 2013. According to average values, April 2009 was the period with the most acidic water and greater $\mathrm{CO}_{2}$ enrichment, followed by June 2012 and May-June 2013 (Table 1). Mean $\Omega_{\mathrm{a}}$ values were $2.71 \pm 0.29$ during the upwelling season (April 2009) and $3.41 \pm 0.13$ during the non-upwelling season (June 2012, May-June 2013), resulting in annual average $\Omega_{\mathrm{a}}$ of $3.06 \pm 0.49$ at Bahía Culebra. Time series of $\mathrm{pH}$ and $p \mathrm{CO}_{2}$ in June 2012 and May-June 2013 showed a pronounced daily cycle (Fig. 4), which in addition to previously described data will be discussed in the following paragraphs.

\section{Discussion}

\subsection{Natural OA beyond the upwelling season}

The observed differences in $\mathrm{pH}$ and $p \mathrm{CO}_{2}$ between 2012 and 2013 suggest that the non-upwelling season exhibits a strong interannual variability (Table 1). In 2012, $\mathrm{pH}$ was lower and $p \mathrm{CO}_{2}$ higher than in 2013 (Fig. 2b, c). The June 2012 time 

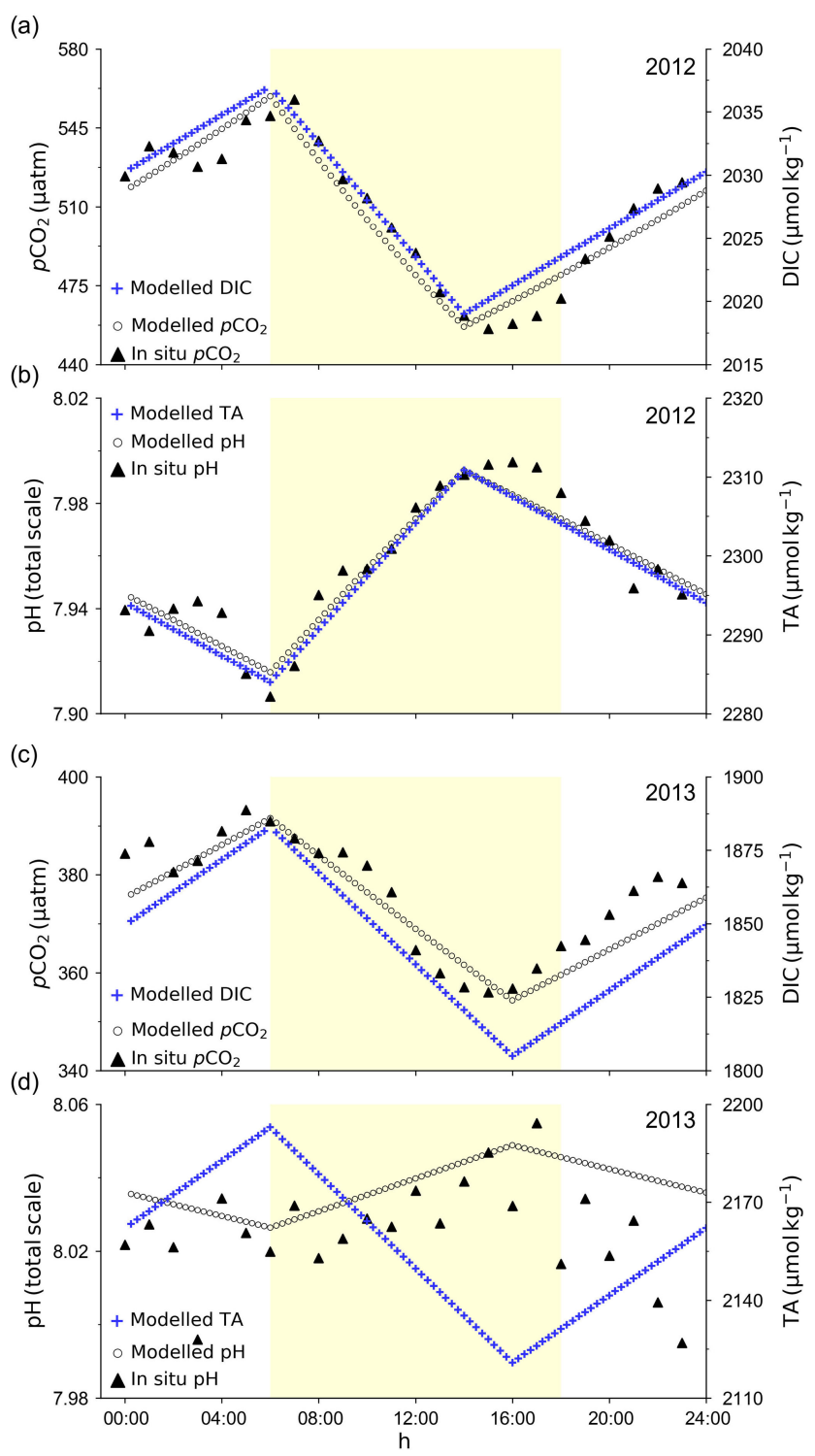

Figure 5. Expected diel behavior of the carbonate system in 2012 (a, b) and 2013 (c, d), based on measured parameters. Modeled parameters are shown as blue crosses and empty circles; the reference parameter used to adjust the model is shown in black triangles. Shaded area represents daylight hours.

series data showed that SWT decreased and $p \mathrm{CO}_{2}$ increased from 300 to $650 \mu \mathrm{atm}$ in less than a week, after several days of strong afternoon winds (Fig. 2a). Similarly, this increase in $p \mathrm{CO}_{2}$ was accompanied by a drop in $\mathrm{pH}$ from 8.04 to 7.83 (Fig. 2a). This suggests that an enhanced wind-driven vertical mixing entrained cooler and $\mathrm{CO}_{2}$-enriched waters from greater water depth into the surface layer. The associated SWT drop from 31.4 to $27.1^{\circ} \mathrm{C}$ was similar to that observed during the onset of the 2009 upwelling event $\left(26.2\right.$ to $23.7^{\circ} \mathrm{C}$; Rixen et al., 2012). Nevertheless, the higher SWT during the 2012 non-upwelling season suggests that the entrained wa-
Table 2. Correlations between tide height and four parameters during the non-upwelling seasons $(2012,2013)$.

\begin{tabular}{rrrrr}
\hline Year & $\mathrm{pH}$ & $p \mathrm{CO}_{2}$ & $T$ & Wind \\
\hline 2012 & -0.004 & 0.037 & -0.005 & 0.033 \\
2013 & 0.111 & 0.026 & -0.093 & -0.126 \\
\hline
\end{tabular}

All $p$ values $>0.05$.

ter originated from a shallower water depth, compared with the water upwelled in 2009. The $p \mathrm{CO}_{2}$ values with up to $650 \mu$ atm reached the same level during both events, which is partially caused by the higher SWT in 2012. However, DIC concentrations in $2012\left(1924.65 \pm 195.07 \mu \mathrm{mol} \mathrm{kg}^{-1}\right)$ were lower than those in $2009\left(2098.71 \pm 103.81 \mu \mathrm{mol} \mathrm{kg}^{-1}\right)$ but exceeded those in $2013\left(1800.92 \pm 142.78 \mu \mathrm{mol} \mathrm{kg}^{-1}\right.$; Table 1). During the 7 days of the cold-water intrusion event in 2012 (10-17 June), the DIC concentrations dropped from $2355.39 \mu \mathrm{mol} \mathrm{kg} \mathrm{kg}^{-1}$ down to $1715.30 \mu \mathrm{mol} \mathrm{kg}{ }^{-1}$. This implies that in addition to high SWT, the entrainment of $\mathrm{CO}_{2}$ enriched subsurface water increased the $p \mathrm{CO}_{2}$ not only during the upwelling periods but also during the 2012 nonupwelling season.

Since in 2012 the $p \mathrm{CO}_{2}$ had already increased by 7 June and the SWT decreased 2 days later (10 June), the inflow of $\mathrm{CO}_{2}$-enriched waters seems to have increased the $p \mathrm{CO}_{2}$ already prior to the strengthening of local winds (Fig. 2b). Later, local wind-induced vertical mixing seems to have amplified the impact of the inflowing $\mathrm{CO}_{2}$-enriched water mass on the $p \mathrm{CO}_{2}$ in the surface water by increasing its input into surface layers. Accordingly, the $\mathrm{CO}_{2}$-enriched waters were apparently supplied from a different location than they are during the upwelling season. Since the NECC carries offshore waters towards the Costa Rican shore during the nonupwelling season (Wyrtki, 1965, 1966; Fiedler, 2002), it is assumed that the $\mathrm{CO}_{2}$-enriched subsurface water originated somewhere south of our study area in the open ETP. The absence of such a cold event during the non-upwelling season in 2013 suggests that the occurrence of this kind of event might be an irregular feature (Fig. 2c, d), and the driving forces are still elusive. Nevertheless, these types of events have the potential to affect the metabolic processes in the bay as will be discussed in the following section, which analyzes the daily cycles during the non-upwelling seasons in 2012 and 2013.

\subsection{Processes behind the variability of the carbonate system}

In 2012, the $\mathrm{pH}$ and the $p \mathrm{CO}_{2}$ values followed a pronounced diurnal cycle with highest $\mathrm{pH}$ and lowest $p \mathrm{CO}_{2}$ values during the late afternoon and lowest $\mathrm{pH}$ and highest $p \mathrm{CO}_{2}$ values around sunrise in the early morning (Fig. 4a). Such daily cycles are typical for tropical regions and are assumed to be 
caused by photosynthesis during the day and respiration of organic matter during the night (Shaw et al., 2012; Albright et al., 2013; Cyronak et al., 2013a). The aragonite saturation state as well as the DIC / TA ratio followed this pattern, with higher $\Omega_{\mathrm{a}}$ and lower DIC / TA ratio values during the day as well as lower $\Omega_{\mathrm{a}}$ and higher DIC / TA values at night (Fig. 4b). Although the $p \mathrm{CO}_{2}$ cycles in 2013 followed a similar pattern to 2012, pH cycles were less predictable (Fig. 4).

To characterize the relative importance of the processes responsible for the observed changes in $\mathrm{pH}$ and $\mathrm{pCO}_{2}$ (photosynthesis, respiration, calcification and dissolution), we used the model described earlier, which is based on the determined DIC concentrations during times when $\mathrm{pH}$ and $p \mathrm{CO}_{2}$ revealed their daily minima and maxima, respectively. For example, if photosynthesis of organic matter dominates the transition from early morning maxima of $p \mathrm{CO}_{2}$ to late afternoon minima of $p \mathrm{CO}_{2}$, it should be associated with a decline in DIC. Whether photosynthesis was accompanied with enhanced calcification can be detected by an associated decrease of TA. Since decreasing DIC raises the $\mathrm{pH}$ and a decrease in TA lowers the $\mathrm{pH}$, such photosynthetic-enhanced calcification hardly affects the $\mathrm{pH}$ and could explain the weak daily cycle observed in 2013. Alternatively, if photosynthesis is accompanied by carbonate dissolution during the day, this would amplify the daily cycle of $\mathrm{pH}$ and $p \mathrm{CO}_{2}$ as seen during the cold-water intrusion event in 2012. Likewise, an increased photosynthesis resulting from higher nutrient concentrations (Pennington et al., 2006) could also be causing the observed large amplitude during the event in 2012. However, in our case, the determined TA and DIC concentrations constrain the impact of the formation of organic matter (POC is equivalent to photosynthesis minus respiration) and calcification (PIC is equivalent to calcification minus dissolution) on the carbonate system. This sets the boundaries within which the observed diurnal cycle of $\mathrm{pH}$ and $p \mathrm{CO}_{2}$ has to be explained (Fig. 5c, d). In order to reconstruct the diurnal cycle of $\mathrm{pH}$ and $\mathrm{pCO}_{2}$ within these boundaries, we assumed a photosynthetic-enhanced calcification during the day, and vice versa dissolution and respiration at night. Thereby, the best fit between $\mathrm{pH}$ and $p \mathrm{CO}_{2}$ measured in 2013 and the respective calculated values could be obtained by using a $R_{\mathrm{OI}}$ of 1. This approach failed to explain the diurnal cycle of $\mathrm{pH}$ and $p \mathrm{CO}_{2}$ as observed during the 2012 cold-water intrusion event (10-17 June). The only solution we found to explain these pronounced diurnal cycles within the given DIC and TA boundaries was to assume that photosynthesis and dissolution prevailed during the day and respiration and calcification occurred at night. The $R_{\mathrm{OI}}$ of -2.6 resulted in the best fit between the measured and calculated $\mathrm{pH}$ and $\mathrm{pCO}_{2}$ for the 2012 event, whereas the negative sign reflects the contrasting effects of calcification and dissolution on the DIC concentration.

Dissolution taking place during daytime is peculiar but not completely unusual, as it has been reported on tropical sandy bottoms under ambient (Yates and Halley, 2006a, b;
Cyronak et al., 2013b) and high- $\mathrm{CO}_{2}$ conditions (Comeau et al., 2015). Similarly, dark calcification is not entirely uncommon and occurs in both sandy bottoms and coral reefs (Yates and Halley, 2006b; Albright et al., 2013). Accordingly, the entrainment of $\mathrm{CO}_{2}$-enriched water from the NECC seems to shift the carbonate chemistry of Bahía Culebra from a system where photosynthesis and calcification are the controlling processes during daylight hours to a system in which daytime is dominated by photosynthesis and dissolution. The net effect, as observed, is an enhanced $p \mathrm{CO}_{2}$ and lower $\Omega_{\mathrm{a}}$ during periods characterized by the inflow of $\mathrm{CO}_{2}$-enriched waters (Table 1). This has strong ecological implications for local coral reef ecosystems.

\subsection{Ecological implications for coral reefs}

Coral reefs in Bahía Culebra were dominated by Pocillopora spp. and Pavona clavus (Jiménez, 2001; Jiménez et al., 2010), whereas Porites lobata is the main reef forming coral in the southern part of the Costa Rican Pacific coast (Cortés and Jiménez, 2003; Glynn et al., 2017). Although the reefs in the north are naturally exposed to periodic high- $\mathrm{CO}_{2}$ conditions during upwelling events (Rixen et al., 2012), as well as during cold-water intrusions in the non-upwelling season, the linear extension rates of Pocillopora spp. and P. clavus exceeded those of the same species in other regions (Fig. 6) (Glynn, 1977; Jiménez and Cortés, 2003; Manzello, 2010a; Rixen et al., 2012). This suggests that local corals are adapted and/or acclimatized to the upwelling of cold and acidic waters.

Aragonite saturation state $\left(\Omega_{\mathrm{a}}\right)$ is known as one of the main variables influencing coral growth and therefore reef distribution around the world (Kleypas et al., 1999). By integrating the data from the present study and values previously reported by Rixen et al. (2012), we estimated that the annual mean $\Omega_{\mathrm{a}}$ in Bahía Culebra is 3.06. Additionally, earlier studies in the ETP measured $\Omega_{\mathrm{a}}$ values and coral extension rates from locations that are under the influence of upwelling events (Manzello, 2010a), whilst extension rates from Bahía Culebra were measured by Jiménez and Cortés (2003). The correlation between our estimated $\Omega_{\mathrm{a}}$ with the available data from Bahía Culebra, Panama and Galápagos indicates that coral extension rates in each of those locations are predictable by their corresponding $\Omega_{\mathrm{a}}$ values (Fig. 6).

The dependency of coral growth on $\Omega_{\mathrm{a}}$ and the mean $\Omega_{\mathrm{a}}$ (2.71) during the upwelling season (Table 1) suggests that upwelling of acidic waters should reduce corals' relatively high annual mean growth rates in Bahía Culebra. The increased $\Omega_{\mathrm{a}}$ during the non-upwelling season in turn must enhance linear extension and explains corals' high annual mean growth rates. The $\Omega_{\mathrm{a}}$ values from this study suggest that most favorable conditions for coral growth occur during the non-upwelling season, the period that coincides with development of the rainy season. This implies that during the main growing season the eutrophication and siltation caused 

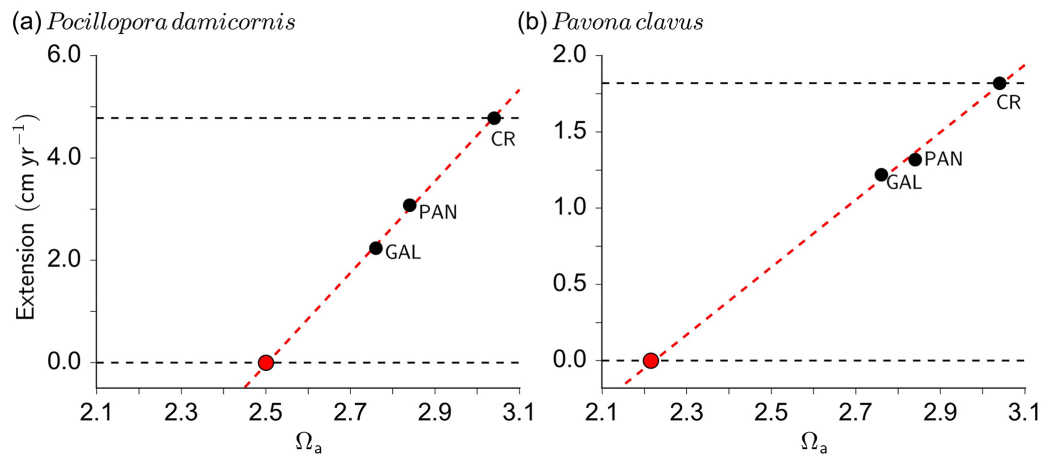

Figure 6. Mean aragonite saturation states $\left(\Omega_{\mathrm{a}}\right)$ - from present and former studies - versus previously reported mean linear extension rates of (a) Pocillopora damicornis and (b) Pavona clavus from upwelling areas in Costa Rica (CR) (Jiménez and Cortés, 2003), Panama (PAN) and Galápagos (GAL) (Manzello, 2010a). The red dotted line shows the regression equation as estimated by Rixen et al. (2012). The red mark represents our estimated $\Omega_{\mathrm{a}}$ threshold for Bahía Culebra, when coral growth equals zero.

by human impacts on river discharges, as well as the development of harmful algal blooms, could also strongly affect the corals' annual mean growth rates (Cortés and Reyes-Bonilla, 2017).

Despite the corals' high annual mean linear extension rates, studies carried out in 1973 showed that the thickness of the reef framework within our study area was with 0.6 to $3 \mathrm{~m}$ (mean $1.8 \mathrm{~m}$ ) among the lowest in the ETP, where Holocene framework accumulation in Pocilloporadominated reefs could reach up to $9 \mathrm{~m}$ (Glynn et al., 1983; Toth et al., 2017). During the last decade, it further decreased (Alvarado et al., 2012), and during the period of our observation the reef frameworks of Pocillopora spp. in Bahía Culebra hardly exceeded a thickness of $0.5 \mathrm{~m}$. This denotes that although Pocillopora spp. and P. clavus are adapted to the entrainment of acidic waters, these reefs are growing in an environment at the limit of reef-building corals' tolerance in terms of temperature, nutrient loads and $\mathrm{pH}$ (Manzello et al., 2017). Gaps in coral reef accretion at the ETP are known from the geological record (Toth et al., 2012, 2015, 2017). They have been linked to increased El Niño-Southern Oscillation (ENSO) variability (Toth et al., 2012, 2015) and stronger upwelling conditions (Glynn et al., 1983), favoring dissolution and erosion of reef frameworks while at the same time restricting coral growth.

The $y$ intercept of the regression equation derived from the correlation between linear extension rates and $\Omega_{\mathrm{a}}$ furthermore implies that linear extension of $P$. damicornis and $P$. clavus should approach zero under a carbonate saturation state of $\Omega_{\mathrm{a}}<2.5$ (P. damicornis) and $<2.2$ (P. clavus). According to climate predictions, the global $\Omega_{\mathrm{a}}$ will reach values $<2.0$ by the end of this century (IPCC, 2014), and major upwelling systems such as those off California and South America will intensify (Wang et al., 2015). Combined effects of ocean acidification and impacts of stronger upwelling on $\Omega_{\mathrm{a}}$ in the ETP and on $\Omega_{\mathrm{a}}$ in Bahía Culebra are difficult to predict. Worldwide, OA is expected to reduce coral reefs' resilience by decreasing calcification and increasing dissolution and bioerosion (Kleypas et al., 1999; Yates and Halley, 2006a; Anthony et al., 2011). Coral reefs from the ETP are affected by chronic and acute disturbances, such as thermal stress and natural ocean acidification resulting from ENSO and upwelling events, respectively (Manzello et al., 2008; Manzello, 2010b). Historically, these reefs have shown a high resilience to both stressors separately, but their coupled interaction can cause coral reefs to be lost within the next decades. The ETP has the lowest $\Omega_{\mathrm{a}}$ of the tropics, near the threshold values for coral reef distribution; therefore, the reefs from this region may be the most affected by the increasing levels of anthropogenic $\mathrm{CO}_{2}$ and also show the first negative impacts of this human-induced OA (Manzello et al., 2017). This emphasizes the importance of the Paris Agreement and all the global efforts to reduce the $\mathrm{CO}_{2}$ emission into the atmosphere (Figueres et al., 2017).

\section{Conclusions}

The present study provides data from in situ measurements from a system that is naturally exposed to low-pH conditions and seeks to characterize the carbonate chemistry within a bay (Bahía Culebra) and its potential impact on the reefs. This study builds on previous field studies in the upwelling areas of Panama (Manzello et al., 2008; Manzello, 2010b) and Papagayo (Rixen et al., 2012). Our results indicate that physical processes, such as the coastal upwelling and the exchange of water between the bay and the open ocean, influence the carbonate chemistry on timescales of weeks to months, where metabolic processes (photosynthesis and calcification) influence the diurnal cycle. To which extent benthic and pelagic processes control the diurnal cycle cannot be established based on our data. However, the results from the present study also suggest that coral reefs from Bahía Culebra are exposed to a high intra- and interannual variability in the carbonate system. Challenging conditions for 
reef development are not restricted to the upwelling season; they occur sporadically also during the non-upwelling season, when $\mathrm{pH}$ and $\mathrm{CO}_{2}$ concentrations reach values comparable to those during upwelling events. Previous studies reported that the linear extension rates measured in Bahía Culebra were among the highest in the ETP; thus, it is likely that coral growth in this bay is enhanced with increased $\Omega_{\mathrm{a}}$ during periods with no entrainment of low-pH waters. However, coral growth must be measured during both seasons in order to confirm this assumption. Threshold values of $\Omega_{\mathrm{a}}$ when coral growth likely approaches zero were derived from the correlation of $\Omega_{\mathrm{a}}$ and previously measured annual linear extension rates. The $\Omega_{\mathrm{a}}$ threshold values from the present study and the fact that high- $\mathrm{CO}_{2}$ waters are occasionally hauled in to the bay during the non-upwelling season suggest that coral reef development in Bahía Culebra is potentially threatened by anthropogenic OA.

Data availability. Data are available by direct request to the corresponding author.

Author contributions. CSN and TR designed the study, analyzed the data, prepared figures and/or tables and wrote the paper. CSN collected and analyzed the samples. IS, JC, ÁM, CJ and CW reviewed the paper.

Competing interests. The authors declare that they have no conflict of interest.

Disclaimer. This study was funded by the Leibniz Association, as part of the PhD research of Celeste Sánchez-Noguera. Funders had no role in conceiving the study, collection and analysis of data or manuscript preparation.

Acknowledgements. This project was conducted in cooperation with the Centro de Investigación en Ciencias del Mar y Limnología (CIMAR), University of Costa Rica. We give special thanks to Marina Papagayo for allowing us to deploy the sensors in their facilities, and Giovanni Bassey and Carlos Marenco for logistic support and sample collection.

Edited by: David Gillikin

Reviewed by: two anonymous referees

\section{References}

Albright, R., Langdon, C., and Anthony, K. R. N.: Dynamics of seawater carbonate chemistry, production, and calcification of a coral reef flat, central Great Barrier Reef, Biogeosciences, 10, 6747-6758, https://doi.org/10.5194/bg-10-6747-2013, 2013.
Alfaro, E. and Cortés, J.: Atmospheric forcing of cool subsurface water events in Bahía Culebra, Gulf of Papagayo, Costa Rica, Rev. Biol. Trop., 60, 173-186, 2012.

Alvarado, J., Cortés, J., and Reyes-Bonilla, H.: Reconstruction of Diadema mexicanum bioerosion impact on three Costa Rican Pacific coral reefs, Rev. Biol. Trop., 60, 121-132, 2012.

Amador, J., Rivera, E., Durán-Quesada, A., Mora, G., Sáenz, F., Calderón, B., and Mora, N.: The easternmost tropical Pacific. Part II: Seasonal and intraseasonal modes of atmospheric variability, Rev. Biol. Trop., 64, S23-S57, 2016.

Anthony, K. R. N., Maynard, J. A., Diaz-Pulido, G., Mumby, P. J., Cao, L., Marshall, P. A., and Hoegh-Guldberg, O.: Ocean acidification and warming will lower coral reef resilience, Glob. Change Biol., 17, 1798-1808, 2011.

Ballestero, D. and Coen, J.: Generation and propagation of anticyclonic rings in the Gulf of Papagayo, Int. J. Remote Sens., 25, 2217-2224, 2004.

Barkley, H., Cohen, A., Golbuu, Y., Starczak, V., Decarlo, T., and Shamberger, K.: Changes in coral reef communities across a natural gradient in seawater $\mathrm{pH}$, Sci. Adv., 1, e1500328, https://doi.org/10.1126/sciadv.1500328, 2015.

Brenes, C., León, S., Gutiérrez, A., and Arroyo, G.: Condiciones Hidrográficas en la Región de los "Papagayos", Rev. Geofísica, 33, 5-19, 1990.

Broecker, W. S. and Peng, T.-H.: Tracers in the sea, LamontDoherty Geological Observatory, Columbia University, Palisades, New York, 1982.

Chelton, D., Freilich, M., and Esbensen, S.: Satellite observations of the wind jets off the Pacific coast of Central America. Part I: Case studies and statistical characteristics, Mon. Weather Rev., 128, 1993-2018, 2000.

Comeau, S., Carpenter, R. C., Lantz, C. A., and Edmunds, P. J.: Ocean acidification accelerates dissolution of experimental coral reef communities, Biogeosciences, 12, 365-372, https://doi.org/10.5194/bg-12-365-2015, 2015.

Cortés, J. and Jiménez, C.: Corals and coral reefs of the Pacific of Costa Rica: History, research and status, in Latin American Coral Reefs, edited by J. Cortés, 361-385, Elsevier Science B.V., Amsterdan, the Netherlands, 2003.

Cortés, J. and Reyes-Bonilla, H.: Human Influences on Eastern Tropical Pacific Coral Communities and Coral Reefs, in: Coral Reefs of the Eastern Tropical Pacific: Persistence and Loss in a Dynamic Environment, edited by: Glynn, P. W., Manzello, D. P., and Enochs, I. C., 549-563, Springer Netherlands, Dordrecht, 2017.

Cullison Gray, S., DeGrandpre, M., Moore, T., Martz, T., Friederich, G., and Johnson, K.: Applications of in situ pH measurements for inorganic carbon calculations, Mar. Chem., 125 , 82-90, https://doi.org/10.1016/j.marchem.2011.02.005, 2011.

Cyronak, T., Santos, I., McMahon, A., and Eyre, B.: Carbon cycling hysteresis in permeable carbonate sands over a diel cycle: Implications for ocean acidification, Limnol. Oceanogr., 58, 131-143, https://doi.org/10.4319/1o.2013.58.1.0131, 2013a.

Cyronak, T., Santos, I. R., Erler, D. V., and Eyre, B. D.: Groundwater and porewater as major sources of alkalinity to a fringing coral reef lagoon (Muri Lagoon, Cook Islands), Biogeosciences, 10, 2467-2480, https://doi.org/10.5194/bg-10-24672013, 2013b 
DeGrandpre, M., Hammar, T., Smith, S., and Sayles, F.: In-Situ Measurements of Seawater $p \mathrm{CO}_{2}$, Limnol. Oceanogr., 40, 969975, 1995.

DeGrandpre, M., Baehr, M., and Hammar, T.: Calibrationfree optical chemical sensors, Anal. Chem., 71, 1152-1159, https://doi.org/10.1021/ac9805955, 1999.

Dickson, A.: Thermodynamics of the dissociation of boric acid in synthetic seawater from 273.15 to 318.15 K, Deep-Sea Res. Pt. A, 37, 755-766, https://doi.org/10.1016/0198-0149(90)90004-F, 1990.

Dickson, A. and Millero, F.: A comparison of the equilibrium constants for the dissociation of carbonic acid in seawater media, Deep-Sea Res. Pt. A, 34, 1733-1743, https://doi.org/10.1016/0198-0149(87)90021-5, 1987.

Dickson, A., Afghan, J., and Anderson, G.: Reference materials for oceanic $\mathrm{CO}_{2}$ analysis: a method for the certification of total alkalinity, Mar. Chem., 80, 185-197, https://doi.org/10.1016/S03044203(02)00133-0, 2003.

Dickson, A., Sabine, C., and Christian, J.: Guide to best practices for ocean $\mathrm{CO}_{2}$ measurements, PICES Special Publication 3, North Pacific Marine Science Organization, Sidney, Canada, 2007.

Doney, S., Fabry, V., Feely, R., and Kleypas, J.: Ocean Acidification: The Other $\mathrm{CO}_{2}$ Problem, Ann. Rev. Mar. Sci., 1, 169-192, https://doi.org/10.1146/annurev.marine.010908.163834, 2009.

Doney, S., Ruckelshaus, M., Duffy, E., Barry, J., Chan, F., English, C., Galindo, H., Grebmeier, J., Hollowed, A., Knowlton, N., Polovina, J., Rabalais, N., Sydeman, W., and Talley, L.: Climate Change Impacts on Marine Ecosystems, Annu. Rev. Mar. Sci., 4, 11-37, https://doi.org/10.1146/annurev-marine-041911111611, 2012.

Enochs, I., Manzello, D., Donham, E., Kolodziej, G., Okano, R., Johnston, L., Young, C., Iguel, J., Edwards, C., Fox, M., Valentino, L., Johnson, S., Benavente, D., Clark, S., Carlton, R., Burton, T., Eynaud, Y., and Price, N.: Shift from coral to macroalgae dominace on a volcanically acidified reef, Nat. Clim. Chang., 5, 1083-1088, https://doi.org/10.1038/nclimate2758, 2015.

Fabricius, K., Langdon, C., Uthicke, S., Humphrey, C., Noonan, S., De'ath, G., Okazaki, R., Muehllehner, N., Glas, M., and Lough, $\mathrm{J} .:$ Losers and winners in coral reefs acclimatized to elevated carbon dioxide concentrations, Nat. Clim. Chang., 1, 165-169, https://doi.org/10.1038/nclimate1122, 2011.

Fabricius, K., Kluibenschedl, A., Harrington, L., Noonan, S., and De'ath, G.: In situ changes of tropical crustose coralline algae along carbon dioxide gradients, Sci. Rep., 5, 9537, https://doi.org/10.1038/srep09537, 2015.

Fabry, V., Seibel, B., Feely, R., and Orr, J.: Impacts of ocean acidification on marine fauna and ecosystem processes, ICES J. Mar. Sci. J. du Cons., 65, 414-432, https://doi.org/10.1093/icesjms/fsn048, 2008.

Fassbender, A., Sabine, C., Feely, R., Langdon, C., and Mordy, C.: Inorganic carbon dynamics during northern California coastal upwelling, Cont. Shelf Res., 31, 1180-1192, https://doi.org/10.1016/j.csr.2011.04.006, 2011.

Feely, R., Sabine, C., Hernández-Ayón, J., Ianson, D., and Hales, B.: Evidence for Upwelling of Corrosive "Acidified" Water onto the Continental Shelf, Science, 320, 1490-1492, https://doi.org/10.1126/science.1155676, 2008.
Feely, R., Doney, S., and Cooley, S.: Ocean acidification: present conditions and future changes in a high- $\mathrm{CO}_{2}$ world, Oceanography, 22, 36-47, 2009.

Fiedler, P.: The annual cycle and biological efects of the Costa Rica Dome, Deep. Res., 49, 321-338, 2002.

Fiedler, P. and Talley, L.: Hydrography of the eastern tropical Pacific: A review, Prog. Oceanogr., 69, 143-180, https://doi.org/10.1016/j.pocean.2006.03.008, 2006.

Figueres, C., Schellnhuber, H. J., Whiteman, G., Rockström, J., Hobley, A., and Rahmstorf, S.: Three years to safeguard our climate, Nature, 546, 593-595, https://doi.org/10.1038/546593a, 2017.

Gattuso, J., Hoegh-Guldberg, O., and Pörtner, H.: Cross-chapter box on coral reefs, in: Climate Change 2014: Impacts, Adaptation, and Vulnerability. Part A: Global and Sectoral Aspects. Contribution of Working Group II to the Fifth Assessment Report of the Intergovernmental Panel on Climate Change, edited by: Field, C., Barrros, V., Dokken, D., Mach, K., Mastrandrea, M., Bilir, T., Chatterjee, M., Ebi, K., Estrada, Y., Genova, R., Girma, B., Kissel, E., Levy, A., MacCracken, S., Mastrandrea, P., and White, L., 97-100, Cambridge University Press, Cambridge, UK and New York, NY, USA, 2014.

Gattuso, J., Magnan, A., Bille, R., Cheung, W., Howes, E., Joos, F., Allemand, D., Bopp, L., Cooley, S., Eakin, C., Hoegh-Guldberg, O., Kelly, R., Pörtner, H., Rogers, A., Baxter, J., Laffoley, D., Osborn, D., Rankovic, A., Rochette, J., Sumaila, U., Treyer, S., and Turley, C.: Contrasting futures for ocean and society from different anthropogenic $\mathrm{CO}_{2}$ emissions scenarios, Science, 349, aac4722, https://doi.org/10.1126/science.aac4722, 2015.

Glynn, P.: Coral growth in upwelling and nonupwelling areas off the Pacific coast of Panama, J. Mar. Res., 35, 567-585, 1977.

Glynn, P., Druffel, E., and Dunbar, R.: A dead Central American coral reef tract: Possible link with the Little Ice Age, J. Mar. Res., 41, 605-637, https://doi.org/10.1357/002224083788519740, 1983.

Glynn, P. W., Alvarado, J. J., Banks, S., Cortés, J., Feingold, J. S., Jiménez, C., Maragos, J. E., Martínez, P., Maté, J. L., Moanga, D. A., Navarrete, S., Reyes-Bonilla, H., Riegl, B., Rivera, F., Vargas-Ángel, B., Wieters, E. A., and Zapata, F. A.: Eastern Pacific Coral Reef Provinces, Coral Community Structure and Composition: An Overview, in: Coral Reefs of the Eastern Tropical Pacific: Persistence and Loss in a Dynamic Environment, edited by: Glynn, P. W., Manzello, D. P., and Enochs, I. C., 107176, Springer Netherlands, Dordrecht, 2017.

Gray, S., DeGrandpre, M., Langdon, C., and Corredor, J.: Shortterm and seasonal $\mathrm{pH}, p \mathrm{CO}_{2}$ and saturation state variability in a coral-reef ecosystem, Global Biogeochem. Cy., 26, 1-13, https://doi.org/10.1029/2011GB004114, 2012.

Hall-Spencer, J., Rodolfo-Metalpa, R., Martin, S., Ransome, E., Fine, M., Turner, S., Rowley, S., Tedesco, D., and Buia, M.: Volcanic carbon dioxide vents show ecosystem effects of ocean acidification, Nature, 454, 96-99, https://doi.org/10.1038/nature07051, 2008.

Hall-Spencer, J., Thorndyke, M., and Dupont, S.: Impact of Ocean Acidification on Marine Organisms - Unifying Principles and New Paradigms, Water, 7, 5592-5598, https://doi.org/10.3390/w7105592, 2015. 
Harris, K., DeGrandpre, M., and Hales, B.: Aragonite saturation state dynamics in a coastal upwelling zone, Geophys. Res. Lett., 40, 2720-2725, https://doi.org/10.1002/grl.50460, 2013.

Hauri, C., Gruber, N., Plattner, G., Alin, S., Feely, R., Hales, B., and Wheeler, P.: Ocean Acidification in the California Current System, Oceanography, 22, 60-71, https://doi.org/10.5670/oceanog.2009.97, 2009.

Hoegh-Guldberg, O., Mumby, P., Hooten, A., Steneck, R., Greenfield, P., Gomez, E., Harvell, C., Sale, P., Edwards, A., Caldeira, K., Knowlton, N., Eakin, C., Iglesias-Prieto, R., Muthiga, N., Bradbury, R., Dubi, A., and Hatziolos, M.: Coral reefs under rapid climate change and ocean acidification, Science, 318, 1737-1742, https://doi.org/10.1126/science.1152509, 2007.

Hofmann, G., Barry, J., Edmunds, P., Gates, R., Hutchins, D., Klinger, T., and Sewell, M.: The effect of ocean acidification on calcifying organisms in marine ecosystems: an organism-toecosystem perspective, Annu. Rev. Ecol. Evol. Syst., 41, 127147, https://doi.org/10.1146/annurev.ecolsys.110308.120227, 2010.

IPCC: Climate Change 2014: Climate Change 2014: Impacts, Adaptation, and Vulnerability. Part B: Regional Aspects. Contribution of Working Group II to the Fifth Assessment Report of the Intergovernmental Panel on Climate Change, edited by: Barros, V. R., Field, C. B., Dokken, D. J., Mastrandrea, M. D., Mach, K. J., Bilir, T. E., Chatterjee, M., Ebi, K. L., Estrada, Y. O., Genova, R. C., Girma, B., Kissel, E. S., Levy, A. N., MacCracken, S., Mastrandrea, P. R., and White, L. L., Cambridge University Press, Cambridge, UK and New York, NY, USA, 2014.

Jiménez, C.: Arrecifes y ambientes coralinos de Bahía Culebra, Pacífico de Costa Rica: Aspectos biológicos, económicorecreativos y de manejo, Rev. Biol. Trop., 49, 215-231, 2001.

Jiménez, C. and Cortés, J.: Growth of Seven Species of Scleractinian Corals in an Upwelling Environment of the Eastern Pacific (Golfo de Papagayo, Costa Rica), Bull. Mar. Sci., 72, 187-198, 2003.

Jiménez, C., Bassey, G., Segura, A., and Cortés, J.: Characterization of the coral communities and reefs of two previously undescribed locations in the upwelling region of Gulf of Papagayo (Costa Rica), Rev. Mar. Cost., 2, 95-108, 2010.

Kessler, W.: The circulation of the eastern tropical Pacific: A review, Prog. Oceanogr., 69, 181-217, https://doi.org/10.1016/j.pocean.2006.03.009, 2006.

Kleypas, J. and Langdon, C.: Coral reefs and changing seawater carbonate chemistry, in: Coral Reefs and Climate Change: Science and Management, edited by: Phinney, J., Hoegh-Guldberg, O., Kleypas, J., Skirving, W., and Strong, A., 73-110, AGU Monograph Series, Coastal and Estuarine Studies, Am. Geophys. Union, Washington DC, 2006.

Kleypas, J. and Yates, K.: Coral Reefs and Ocean Acidification, Oceanography, 22, 108-117, https://doi.org/10.5670/oceanog.2009.101, 2009.

Kleypas, J. A., Buddemeier, R. W., Archer, D., Gattuso, J.-P., Langdon, C., and Opdyke, B. N.: Geochemical consequences of increased atmospheric carbon dioxide on coral reefs, Science, 284, 118-120, 1999.

Kleypas, J. A., Feely, R. A., Fabry, V. J., Langdon, C., Sabine, L., and Robbins, L. L.: Impacts of Ocean Acidification on Coral Reefs and Other Marine Calcifiers: A Guide for Future Research, report of a workshop held 18-20 April 2005, St. Petersburg,
FL, sponsored by NSF, NOAA, and the U.S. Geological Survey, 88 pp., 2006.

Kroeker, K., Micheli, F., Gambi, M., and Martz, T.: Divergent ecosystem responses within a benthic marine community to ocean acidification, P. Natl. Acad. Sci. USA, 108, 14515-14520, https://doi.org/10.1073/pnas.1107789108, 2011.

Langdon, C., Takahashi, T., Sweeney, C., Chipman, D., Goddard, J., Marubini, F., Aceves, H., Barnett, H., and Atkinson, M.: Effect of calcium carbonate saturation state on the calcification rate of an experiment coral reef, Global Biogeochem. Cy., 14, 639-654, 2000.

Manzello, D.: Reef development and resilience to acute (El Niño warming) and chronic (high- $\mathrm{CO}_{2}$ ) disturbances in eastern tropical Pacific: a real-world climate change model, in Procceedings of the 11th International Coral Reef Symposium, 1299-1303, Ft. Lauderdale, Florida, 2008.

Manzello, D.: Coral growth with thermal stress and ocean acidification: lessons from the eastern tropical Pacific, Coral Reefs, 29, 749-758, https://doi.org/10.1007/s00338-010-0623-4, 2010a.

Manzello, D.: Ocean acidification hotspots: Spatiotemporal dynamics of the seawater $\mathrm{CO}_{2}$ system of eastern Pacific coral reefs, Limnol. Oceanogr., 55, 239-248, https://doi.org/10.4319/lo.2010.55.1.0239, 2010b.

Manzello, D., Kleypas, J., Budd, D., Eakin, C., Glynn, P., and Langdon, C.: Poorly cemented coral reefs of the eastern tropical Pacific: possible insights into reef development in a high$\mathrm{CO}_{2}$ world, P. Natl. Acad. Sci. USA, 105, 10450-10455, https://doi.org/10.1073/pnas.0712167105, 2008.

Manzello, D., Enochs, I., Bruckner, A., Renaud, P., Kolodziej, G., Budd, D., Carlton, R., and Glynn, P.: Galápagos coral reef persistence after ENSO warming across an acidification gradient, Geophys. Res. Lett., 41, 9001-9008, https://doi.org/10.1002/2014GL062501, 2014.

Manzello, D. P., Eakin, C. M., and Glynn, P. W.: Effects of global warming and ocean acidification on carbonate budgets of Eastern Pacific coral reefs, in: Coral Reefs of the Eastern Tropical Pacific: Persistence and Loss in a Dynamic Environment, edited by: Glynn, P. W., Manzello, D. P., and Enochs, I. C., 517-533, Springer Netherlands, Dordrecht, 2017.

Marubini, F., Ferrier-Pagès, C., Furla, P., and Allemand, D.: Coral calcification responds to seawater acidification: a working hypothesis towards a physiological mechanism, Coral Reefs, 27, 491-499, https://doi.org/10.1007/s00338-008-0375-6, 2008.

McCreary, J., Lee, H., and Enfield, D.: The response of the coastal ocean to strong offshore winds: with application to circulations in the Gulfs of Tehuantepec and Papagayo, J. Mar. Res., 47, 81$109,1989$.

Mehrbach, C., Culberson, C., Hawley, J., and Pytkowicz, R.: Measurement of the apparent dissociation constants of carbonic acid in seawater at atmospheric pressure, Limnol. Oceanogr., 18, 897907, https://doi.org/10.4319/lo.1973.18.6.0897, 1973.

Millero, F. J.: The marine inorganic carbon cycle, Chem. Rev., 107, 308-341, 2007.

Pennington, J. T., Mahoney, K. L., Kuwahara, V. S., Kolber, D. D., Calienes, R., and Chavez, F. P.: Primary production in the eastern tropical Pacific: a review, Prog. Oceanogr., 69, 285-317, https://doi.org/10.1016/j.pocean.2006.03.012, 2006.

Pörtner, H., Karl, D., Boyd, P., Cheung, W., Lluch-Cota, S., Nojiri, Y., Schmidt, D., and Zavialov, P.: Ocean systems, in: Climate 
Change 2014: Impacts, Adaptation, and Vulnerability. Part A: Global and Sectoral Aspects. Contribution of Working Group II to the Fifth Assessment Report of the Intergovernmental Panel on Climate Change, edited by: Field, C. B., Barros, V., Dokken, D. J., Mach, K. J., Mastrandrea, M. D., Bilir, T. E., Chatterjee, M., Ebi, K. L., Estrada, Y. O., Genova, R. C., Girma, B., Kissel, E. S., Levy, A. N., MacCracken, S., Mastrandrea, P. R., and White, L. L., Cambridge University Press, Cambridge, UK and New York, NY, USA, 2014.

Rixen, T., Jiménez, C., and Cortés, J.: Impact of upwelling events on the sea water carbonate chemistry and dissolved oxygen concentration in the Gulf of Papagayo (Culebra Bay), Costa Rica: Implications for coral reefs, Rev. Biol. Trop., 60, 187-195, 2012.

Sabine, C., Feely, R., Gruber, N., Key, R., Lee, K., Bullister, J., Wanninkhof, R., Wong, C., Wallace, D., Tilbrook, B., Millero, F., Peng, T., Kozyr, A., Ono, T., and Rios, A.: The oceanic sink for anthropogenic $\mathrm{CO}_{2}$, Science, 305, 367-371, https://doi.org/10.1126/science.1097403, 2004.

Seidel, M., DeGrandpre, M., and Dickson, A.: A sensor for in situ indicator-based measurements of seawater $\mathrm{pH}$, Mar. Chem., 109, 18-28, https://doi.org/10.1016/j.marchem.2007.11.013, 2008.

Shaw, E., McNeil, B., and Tilbrook, B.: Impacts of ocean acidification in naturally variable coral reef flat ecosystems, J. Geophys. Res.-Ocean., 117, 1-14, https://doi.org/10.1029/2011JC007655, 2012.

Stuhldreier, I., Sánchez-Noguera, C., Roth, F., Cortés, J., Rixen, T., and Wild, C.: Upwelling increases net primary production of corals and reef-wide gross primary production along the Pacific coast of Costa Rica, Front. Mar. Sci., 2, 113, https://doi.org/10.3389/fmars.2015.00113, 2015a.

Stuhldreier, I., Sánchez-Noguera, C., Roth, F., Jiménez, C., Rixen, T., Cortés, J., and Wild, C.: Dynamics in benthic community composition and influencing factors in an upwelling-exposed coral reef on the Pacific coast of Costa Rica, PeerJ, 3, e1434, https://doi.org/10.7717/peerj.1434, 2015b.
Takahashi, T., Sutherland, S., Chipman, D., Goddard, J., and Ho, C.: Climatological distributions of $\mathrm{pH}, p \mathrm{CO}_{2}$, total $\mathrm{CO}_{2}$, alkalinity, and $\mathrm{CaCO}_{3}$ saturation in the global surface ocean, and temporal changes at selected locations, Mar. Chem., 164, 95-125, https://doi.org/10.1016/j.marchem.2014.06.004, 2014.

Toth, L., Aronson, R., Vollmer, S., Hobbs, J., Urrego, D., Cheng, H., Enochs, I., Combosch, D., van Woesik, R., and Macintyre, I.: ENSO drove 2500-year collapse of eastern Pacific coral reefs, Science, 337, 81-84, https://doi.org/10.1126/science.1221168, 2012.

Toth, L., Aronson, R., Cobb, K., Cheng, H., Edwards, R., Grothe, P., and Sayani, H.: Climatic and biotic thresholds of coral-reef shutdown, Nat. Clim. Chang., 5, 369-374, https://doi.org/10.1038/nclimate2541, 2015.

Toth, L. T., Macintyre, I. G., and Aronson, R. B.: Holocene reef development in the Tropical Eastern Pacific, in: Coral Reefs of the Eastern Tropical Pacific: Persistence and Loss in a Dynamic Environment, edited by: Glynn, P. W., Manzello, D. P., and Enochs, I. C., 177-201, Springer Netherlands, Dordrecht, 2017.

Wang, D., Gouhier, T. C., Menge, B. A., and Ganguly, A. R.: Intensification and spatial homogenization of coastal upwelling under climate change, Nature, 518, 390-394, 2015.

Wyrtki, K.: Upwelling in the Costa Rica Dome, Fish. Bull., 63, 355372, 1964.

Wyrtki, K.: Surface Currents of the Eastern Tropical Pacific Ocean, Inter-American Trop. Tuna Comm. Bull., IX(5), 271-294, 1965.

Wyrtki, K.: Oceanography of the Eastern Equatorial Pacific Ocean, Ocean. Mar. Biol. Ann. Rev, 4, 33-68, 1966.

Yates, K. K. and Halley, R. B.: $\mathrm{CO}_{3}^{2-}$ concentration and $p \mathrm{CO}_{2}$ thresholds for calcification and dissolution on the Molokai reef flat, Hawaii, Biogeosciences, 3, 357-369, https://doi.org/10.5194/bg-3-357-2006, 2006a.

Yates, K. and Halley, R.: Diurnal variation in rates of calcification and carbonate sediment dissolution in Florida Bay, Estuar. Coasts, 29, 24-39, 2006b. 